\title{
Evaluation of Physico Chemical Qualities of Beeswax in Selected Districts of Kafa Zone, Southern Nations Nationalities and Peoples Region (SNNPR), Ethiopia
}

\author{
Tesfu Shegaw ${ }^{1} \quad$ Asaminew Tassew ${ }^{2}$ Desalegne Begna ${ }^{3}$ \\ 1.Bonga Agricultural Research Center \\ 2. Bahir Dar University \\ 3.Holeta Bee Research Center (HBRC)
}

\begin{abstract}
The study was conducted in selected districts of Kafa Zone of Southern Nations Nationalities and Peoples Region (SNNPR), Ethiopia with an intention to identify the physico chemical quality status of beeswax produced in the areas. Three districts; Chena, Gimbo and Gesha and three peasant associations (PAs) from each district were purposively selected based on their potentialities for production and marketing of honey and beeswax. Before collecting sample beeswaxes, a preliminary survey was conducted to identify the major actors taking part in production, processing and marketing of beeswax. Accordingly, beeswax samples were collected from fresh combs, old combs, local mead houses and cooperatives for detail quality analysis. The Mean \pm SE value for melting point, refractive index, ash content, total volatile matter, acid value, Saponification value, ester value, and ester to acid ratio of beeswax of the area is found to be $62.35 \pm 0.15,1.4416 \pm 0.0001,0.0857 \pm 0.0144$, $0.4156 \pm 0.0385,22.689 \pm 0.3793,94.7540 \pm 0.8617,72.065 \pm 0.4766,3.201 \pm 0.0625$ respectively. All the samples passed for paraffin and other waxes, and fats and fatty acid tests. The result shows no significant variation among studied districts in all parameters. However, significantly higher value of refractive index, total volatile matters and ash contents were recorded in samples from local mead houses at $\mathrm{p}<0.05$. This might be due to poor handling practices and an intentional addition of foreign materials such as salt for preserving beeswax from wax moths' attacks and 'kocho' for increasing its volume which are commonly practiced by some individuals of 'tej' houses. The overall results revealed that all the beeswax samples collected from various sources are found within the acceptable ranges of national and international standards.
\end{abstract}

Keywords: beeswax, physico-chemical qualities, Kafa zone

DOI: $10.7176 / \mathrm{CMR} / 12-1-01$

Publication date: January $31^{\text {st }} 2020$

\section{INTRODUCTION}

Beeswax is a valuable natural product obtained from honeybees secreted from four pairs of glands located underside of the abdomen of young worker bees which arefully developed during 12 to 18 days of age andstartsdiminishingas their age isincreasingand during feed shortages (Brown, 2010; Carillo et al., 2015). However, it will be reactivated in times of emergency or during shortages of younger bees (Bogdanov, 2016a). Honeybees produce wax for constructing their combs and cell capping for storing honey, pollen and rearing broods (Bradbear, 2009).Despite its uses for making foundation sheets, beeswax is also widely used in various fields including cosmetics, foods, pharmaceuticals, engineering and industries (Bogdanov, 2004b; 2016b; Hilmi et al., 2011).

Naturally beeswax is composed of esters of fatty acidsincludingmono ester (35\%), diester(14\%), triester (3\%), hydroxyl monoester (4\%), hydroxylpolyester (8\%), various hydrocarbons $(14 \%)$, free acids $(12 \%)$, long chain alcohols (1\%) and other substances(Brian, 2015; CBI,2015). Pure beeswax is whitish in color. However, presence of pollen in the combs and contamination with other substances during processing and storage triggers it to becomeyellowishor yellow brownish(Bogdanov,2016a). As beeswax has a wide range of uses for human beings, it should contain minimum level of contaminations as much as possible (Bogdanov, 2009). Nowadays, various plagiaristic products and toxic contaminants are becoming the major threats impairing its qualitystatuses(Bogdanov, 2004a; EPOPA, 2006; Gemechis Legesse, 2014).Identifying the quality status of this product along each actor will ease the progress for further intervention so as to produce internationally compatible product which is the very issue of beeswax trading. According to various studies such asNuru (2007); Bekele, et al.,(2016); Addisu, et al.,(2017); Yeshitela et al.,(2018) indicated that the physico-chemical quality status of beeswaxin Ethiopia isvarying from place to places or actorsmainlydue tothe variation in its managements practices and intentional adulteration processes.Consequently, identifying the physico-chemical quality status of this product across different areas of the country and market actors is very imperativeto undertake further intervention.Hence, the current study wasprincipally aimed withevaluating the physico chemical quality status of beeswax in thestudy areas obtained from different sources.

Beeswax is a very complex natural product owing its ownphysical properties which could be distinguished 
using various sensory quality testing mechanismssuch as color, odor, consistence, breakability, chewing test, cutting test, splinters testing and rubbing tests. The color of beeswax immediately produced by honeybees is whitish. However, tends to yellowish or yellow brown upon staying and contaminations with pollen and other impurities. Pure beeswax has pleasant,honey like aromas and shows grainy, blunt, not crystalline structure up on breaking the block. It shouldn't stick to teeth whenchewed and it should not stick to fingers when rolled between fingers. It should not stick to knife up on cutting and has uniform consistency. However, this is not the case if contaminated with paraffin, fats and other oils (Bogdanov, 2004b). Though sensory quality detectionmethods seemsto be the simplest and quickest methods, sometimes it might be difficult to clearly detectthe beeswax qualities based on the level of contaminations or adulterations.Hence, detail labanalysis forvarious physico chemicalparameterssuch as melting point,specific gravity, refractive index, acid value, ester value, saponification value, paraffinand other waxes testsare paramount forclearly detectingitsquality status. For our study case the analysis was done for the above listed parameters except specific gravity due to lab equipment.

\section{MATERIALS AND METHODS}

\subsection{Description of the study areas}

The study was conducted in Kafa zone of Southern Nations Nationalities and Peoples Region (SNNPR). Kafa zone is situated at $6^{\circ} 14^{\prime} 28^{\prime \prime}$ to $8^{\circ} 7^{\prime} 11^{\prime \prime}$ ' $\mathrm{N}$ latitude and $35^{\circ} 26^{\prime} 37^{\prime \prime}$ to $36^{\circ} 47^{\prime} 28^{\prime \prime}$ 'E longitude covering an area of 10,602.7 sq. $\mathrm{km}$ (Wikipedia, 2017). The agro ecology of the zone includes11.64\% (Highlands), 59.45\% (mid land) and $28.91 \%$ (low lands).As the area is covered with moist afro mountain rain forests, it has opportunities to receive nearly year-roundrain fall with minimum and maximumrain falls ranging from 1000 to $2200 \mathrm{~mm}$ annually. The minimum and maximum temperature of the zone is 10.1 and $27.5^{\circ} \mathrm{C}$ respectively (Friis, 1992 , USAID, 2005). According to CSA (2017), Kafazone is expected to have a population of 1,102,278(541,682 male and 560,596 female); of whom 963,852(87\%) are rural inhabitants.

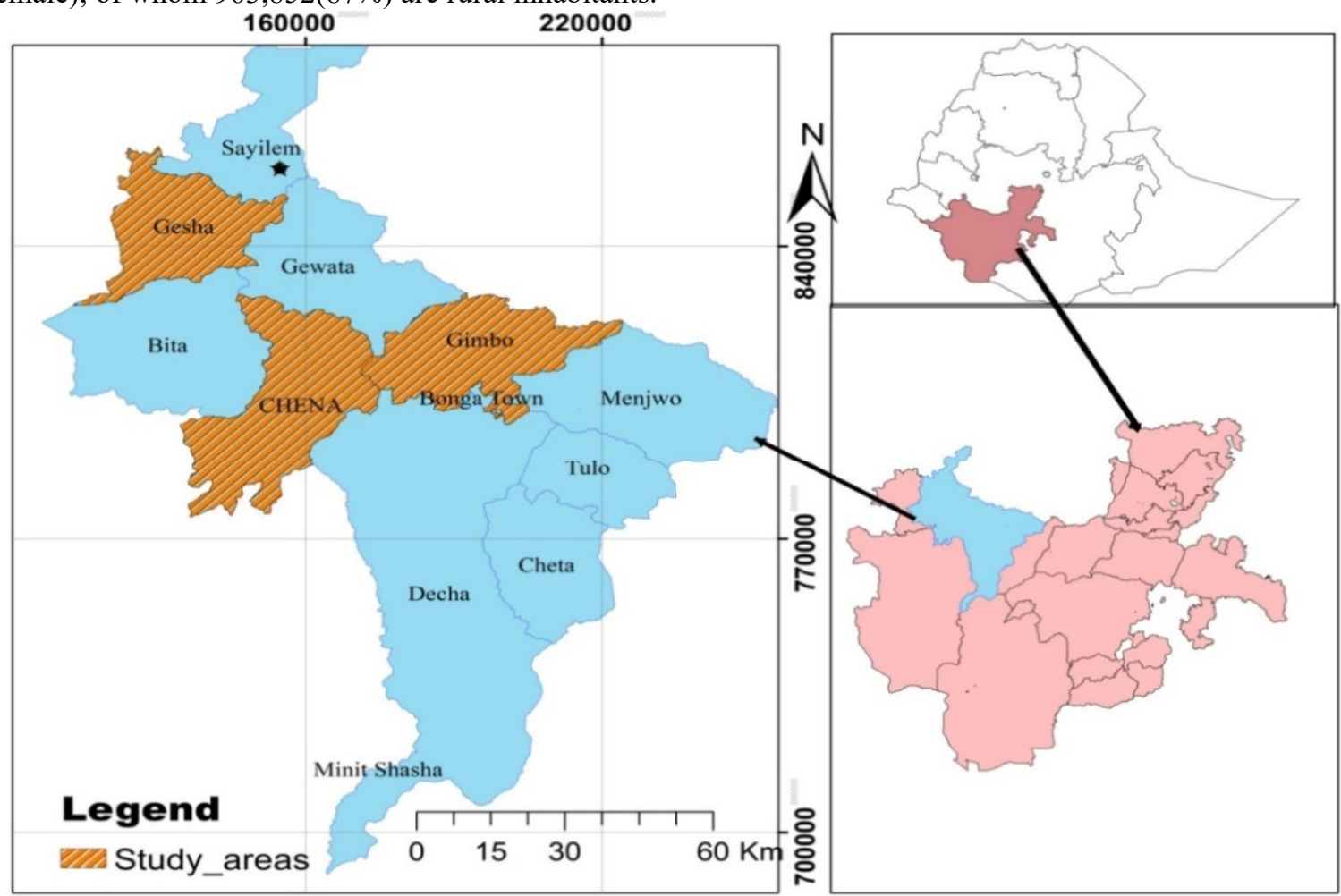

Figure 1. Map of Kafa zone

\subsection{Methods of sample collection and Lab analysis}

The available beeswax samples were collected following the market channels of the three districts (Chena, Gesha and Gimbo). Accordingly, the samples were collected from fresh combs,old combs, local mead/'tej' houses and cooperatives. Beeswax samples from fresh combs were obtained by collecting crude honey from beekeepers producing in bulky amounts and 3- samples were collected from each district. Beeswaxes from old combs were obtained through collecting each available small amount of broken and discarded combs from beekeepers compound/ apiaries. Accordingly, a total of five samples (i.e. 2-from Gesha, 2-from Chena and 1 from Gimbo district were collected. During the time of sample collection, about 14- local mead houses were counted in the studied areas(i.e. 7- in Chena, 4-in Gesha and 3- in Gimbo districts).In the studied areas only 2- cooperatives (1- 
in Chena and 1-in Gesha districts)practicingcollecting, processing and selling beeswax to central markets. Hence, the beeswax samples were collected from both. Hence, a total of 24 beeswax samples from different sources were considered for the study. From each sample sources a minimum of 500gm of beeswax samples were taken by keeping increasing the amount based on the amount of available beeswax source. The collected samples were purifiedusing hot water extraction method, by boiling the beeswax in water and allowing passing through tight clothes/"abujedi"'-Amharic/ and putting in clean, dry and sealable containers and labeled before being sent to lab analysis. The labanalysis was under taken at Sekota Dry land Agricultural Research Center (SDARC) laboratory for its detail physico-chemical qualities. The physico-chemical qualities including melting point, saponification values, refractive index, acid values, ester values, paraffin and other waxes, total volatile matters, fats and fatty acids were investigated based on the detail procedures of Ethiopian beeswax quality specifications ET-12032005(QSAE, 2005).

\subsubsection{Melting point}

To determine the melting point of the beeswax, first the wax was melted by warming it in a water bath at a temperature just sufficient to melt it. Then the thermometer was dipped and withdrawn so as to get the bulb thinly coated with the wax and it was left for 24 hours. After 24 hours, the thermometer was inserted into the test tube through the bored cork and then the test tube was placed in the water bath and the temperature was gradually raised at the rate of $1^{\circ} \mathrm{Cin} 3$ minutes and observing for the first drop of melted wax occurs and recorded as the melting point of the beeswax(QSAE, 2005).

\subsubsection{Refractive index at $75^{\circ} \mathrm{C}$}

The collected wax samples were melted and filtered through fast filter paper in order to remove any impurities and last traces of moistures. The temperature of the refractometer was adjusted at $75+1^{\circ} \mathrm{Cby}$ circulating the water from the water path. A few drops of the sample were placed on the lower prism and the prism was closed and tightened firmlyand allowed to stand for 1-2 minutes.Finally, the refractive index was read and recorded after the sample attained the test temperature(QSAE, 2005).

2.2.3. Ash content, $(\%)$ by mass, $\max$

The platinum dish was heated to redness, cooled to room temperature in desiccators and weighed. Then, about $50 \mathrm{~g}$ of the wax was taken in a watch glass and weighed accurately. About 3/4 of this quantity was transferred to the platinum dish and heated on a Bunsen burner so the wax burns gently at the furnace. When about half of the material burnt, we stopped heating and cooled the sample; we added the remaining material. The material was heatedagain until itwas completely charred.Finally, it was incinerated it in a muffle furnace at $550^{\circ} \mathrm{C}-650^{\circ} \mathrm{C}$ for an hour and then cooled to room temperature in desiccators and weighed. Incineration, cooling and weighing process until was repeated until the difference between successive weightings was less than one milligram(QSAE, 2005). Then, the ash content was determined using the formula;

Ash, percent by mass $=100 M_{2} / M_{1}$

Where, $\mathrm{M}_{2}=$ mass in $\mathrm{g}$ of the ash; $\mathrm{M}_{1}=$ mass in $\mathrm{g}$ of the material taken for the test.

2.2.4. Total volatile matter, $\%$ by mass, max.

A $10 \mathrm{~g}$ of wax was accurately measured in a suitable dish, previously dried and weighed, and placed in an oven maintained at $105^{\circ} \mathrm{C}$ for 6 hours. Then, we cooled the dish in a desiccator and weighing with the lid on and we heated the dish again in the oven for thirty minutes repeating the process until the loss in mass between two successive weightings are less than one milligram and then recording the lowest mass obtained(QSAE, 2005).

Total volatile matter at $105^{\circ} \mathrm{C}$, percent by mass $=\frac{100\left(M_{1}-M_{2}\right)}{M_{1}-M_{3}}$

Where; $\mathrm{M}_{1}$ - mass in gram of the dish with the material before heating; $\mathrm{M}_{2}$ - mass in gram of the dish after heating; $\mathrm{M}_{3}$ - mass in gram of the empty dish

2.2.5. Acid value, max.

We thoroughly mixed the wax until entirely becoming liquid before weighing. Then, a $5 \mathrm{~g}$ of wax was weighed in a $250 \mathrm{ml}$ conical flask and $75 \mathrm{ml}$ of a mixture of two parts of benzene and one part of rectified spirit was added and heated under reflux until the sample is dissolved and allowed to cool to room temperature. Then, titrated with standard potassium hydroxide $(\mathrm{KOH})$ solution using phenolphthalein as indicator(QSAE, 2005).

Acid value $=\frac{56.1 \mathrm{VN}}{M}$

Where; 56.1 -is equivalent weight of Potassium hydroxide $(\mathrm{KOH}), \mathbf{V}=$ volume in $\mathrm{ml}$ of standard potassium hydroxide solution used; $\mathbf{N}=$ normality of standard potassium hydroxidesolution and $\mathbf{M}=$ mass in gram of the material taken for the test.

2.2.6. Saponification cloud point, min.

About $2.0 \mathrm{~g}$ of the wax was weighed in a tarred conical flask and $25 \mathrm{ml}$ of methylketone was added followed by addition of $25 \mathrm{ml}$ of alcoholic potassium hydroxide solution. Then a few pieces of pumice stone were added and reflux condenser was connected to the flask. The flask was heated on a water bath for 2 hours and boiled steadily but gently. The flask and condenser were cooled, and the inside of the condenser was washed with about $10 \mathrm{ml}$ of rectified spirit. Finally about $1 \mathrm{ml}$ of phenolphthalein indicator solution was added and titrated with standard 
hydrochloric acid.Blank determination was carried out at the same time.

Saponification value $=\frac{56.1(B-S) N}{M}$

Where,56.1 -is equivalent weight of Potassium hydroxide $(\mathrm{KOH}) ; \mathrm{B}=$ volume in $\mathrm{ml}$ of standard hydrochloric acid required for the blank; $\mathrm{S}=$ volume in $\mathrm{ml}$ of standard hydrochloric acid required for the material; $\mathrm{N}=$ normality of standard hydrochloric acid (HCL), andM = mass in $\mathrm{g}$ of the beeswax(QSAE, 2005).

\subsubsection{Ester value}

The Easter value can be calculated by subtracting the acid value determined from the saponification value(QSAE, 2005).

Ester value $=$ Saponification value - Acid Value

2.2.8. Fats and fatty acids

To detect the fats and fatty acids content, first $5 \mathrm{~g}$ of the wax was boiled for about 10 minutes with $80 \mathrm{ml}$ of sodium hydroxide solution while adding the water during boiling to replace the water lost due to evaporation. Then, after cooling and filteringthe solution through glass wool, the filtratewas acidifiedby diluting with hydrochloric acid.Then,the material was checked for passing the test. Accordingly, it will pass the test if the solution doesn't become turbid after acidification(QSAE, 2005).

2.2.9. Paraffin and other waxes

To test the paraffin and other wax in beeswax sample, $1 \mathrm{~g}$ of beeswax was weighed and placed in a conical flask fitted with a water-cooled reflux condenser and boiling under reflux for an hour after adding $10 \mathrm{ml}$ of alcoholic $\mathrm{KOH}$ solution. Detaching the flask from the condenser, inserting suitably a thermometer into the liquid in the flask and allow to cool while stirring constantly. Then, the wax samples were checked for passing the test(QSAE, 2005). Accordingly, each sample had passed the test as it doesn't become cloudy at a temperature higher than $61^{\circ} \mathrm{Cbut}$ became cloudy at a temperature between $59^{\circ} \mathrm{C}$ and $61^{\circ} \mathrm{C}$.

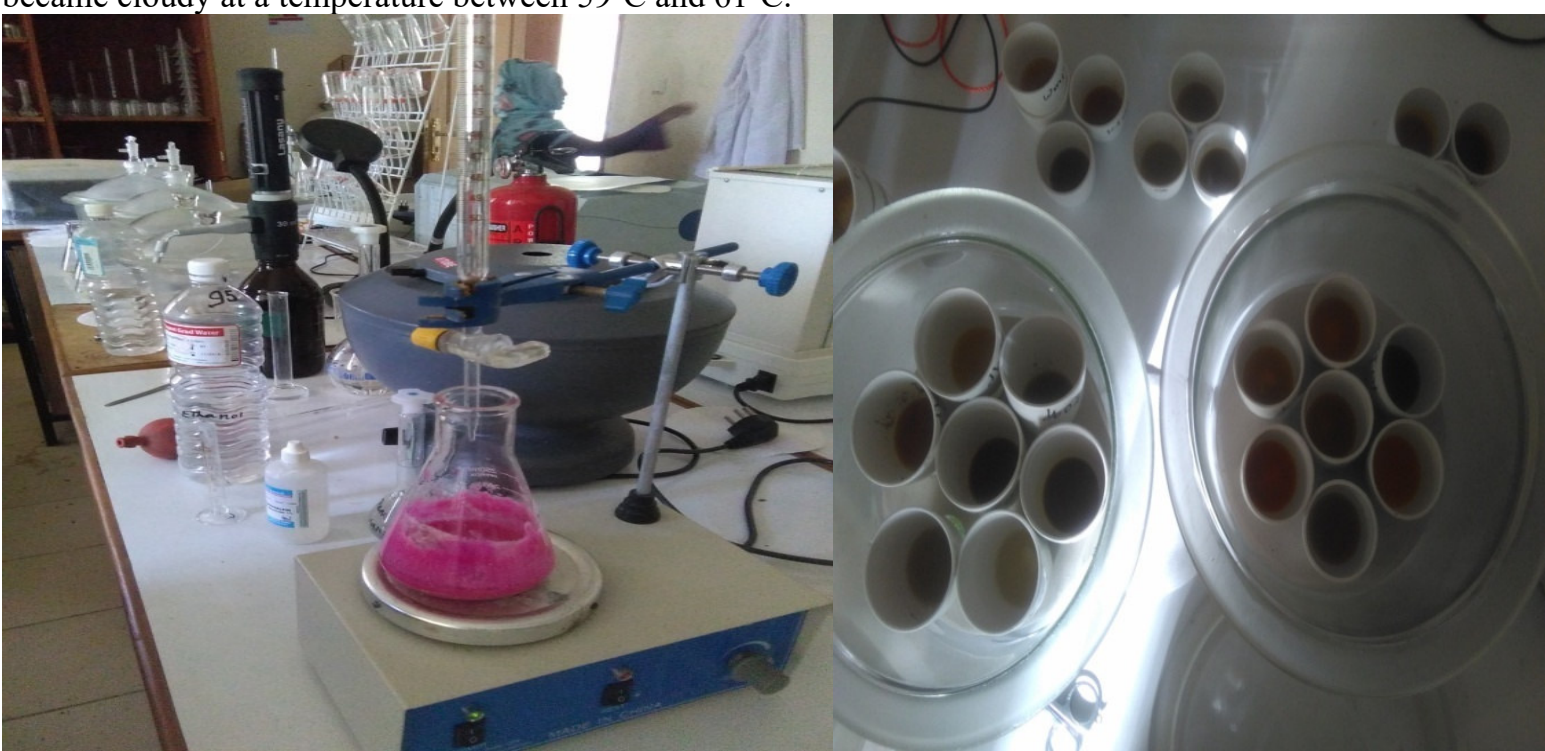

Photo 1: Laboratory analysis

2.2.10. Data Management and Statistical Analysis

The available qualitative data were analysed using Statistical Package for Social Science (SPSS-version 20) software.

Presencesof associations between different quality parameters of samples were tested. The Correlation among different quality tests were used to justify the standards of beeswax in the study areas. Generalized Linear Model $(\mathrm{GLM})$ at $\mathrm{p}<0.05$ level of significances was used to separate the means whenever ANOVA showed statistically significant variations.

The following analysis of variance (ANOVA) model was used for data analysis.

$\boldsymbol{Y}_{i j}=\mu+\boldsymbol{\alpha}_{i}+\mathbf{C}_{i j}$

Where: $Y_{i j}=$ quality of beeswax; $\mu=$ overall mean; $\alpha_{i}=$ the effect of the $i^{\text {th }}$ location or source of beeswax; $\epsilon_{i j}$ $=$ random error

\section{RESULT AND DISCUSSION}

\subsection{Melting point}

The melting point is one of the most important quality parameters used to detect the adulteration of beeswax. The overallmelting point of beeswax $(\mathrm{Mean} \pm \mathrm{SE})$ in the studied areawas measured to be $62.35 \pm 0.15^{\circ} \mathrm{C}$,ranging from 61 to $64^{\circ} \mathrm{C}$. It is found within theacceptable range of national standards $\left(61-66^{\circ} \mathrm{C}\right)$ as well as Kenyan, Tanzanian 
and European standards(Table 4). The melting point of the beeswax in the studied areas doesn't have significant variation among the studied districts as well as different sourcesat $\mathrm{p}<0.05$ (Table 2 and Table 3 ).

\subsection{Refractive Index, at $75^{\circ} \mathrm{C}$}

The refractive index of a substance is the ration of velocity of light in the air to that of an object/substance. It is measured by an apparatus called refractometer. The refractive index of beeswax in the studied areas (Mean \pm SE)was found to be $1.4416 \pm 0.0001$, ranging from 1.4409 to 1.4427 .It satisfies the national standard which is in the range of 1.4400 to 1.4450 . The refractive index of beeswax in the studied areas doesn't have significant variation among studieddistricts (Table 2). However, there is a significant variation based on its sourcesat $\mathrm{p}<0.05$ (Table 3). Accordingly, significantly higher refractive index value was recorded on beeswax sourced fromlocal mead/'tej' houses. This might be due to some impurities found in waxes from 'tej' houses due to contaminations with dusts or other impurities.

\subsection{The ash content, $\%$ by mass, max.}

The ash content is used to determine either the wax is contaminated with soils and other impurities or not. The ash content of beeswax produced in the current studied area(Mean+SE) wasfound to be $0.0856 \pm 0.0144$, ranging from 0.0115 to 0.2354 (Table 1 ). It is within the acceptable national standards $(0.2 \%)$. The ash content of the beeswax in the studied area was significantly vary based on its sourcesat $p<0.05$. Accordingly, the beeswax sample from local mead/'tej' houses has significantly higher ash contents thanbeeswax from fresh combs, cooperatives and old combs(Table 3). This might be due to the fact that beeswax from local mead/ 'tej' house ismore likely prone for contamination with soils or other impurities during storages and processing. Similarly, higher ash contents, 0.051was recorded for beeswax samples collected from tej houses found at different regions of the country (Oromia,Amhara, Tigray and SNNPR)(Yeshitelaet al.,2018). The current result is somehow greater than the ash content report from South Wollo zone which isreported to be 0.0345(Addisuet al.,2017).The higher ash content might be resulted from the additionof table salt $(\mathrm{NaCl})$ on beeswaxat ' $t e j$ ' houses as a preservation mechanism from wax moth attacks, contamination with other impurities which are added for 'tej'/local beer making such as 'Gesho/Rhamnus prinoides'(Photo:2)andthe poor management practices.

\subsection{Total volatile matter, $\%$ by mass, max.}

The total volatile matter in beeswax includes all substance other than moisture which is lost in the form of vapor during combustion in dry oven. The maximum limit for acceptable total volatile matter of beeswax in Ethiopian Standard is 0.75 . The total volatile matter for beeswax in the studied areas (Mean+SE) was foundto be $0.4156+0.0385$ ranging from 0.1919 to 0.8721 (Table 1 ).

The current result revealed that the total volatile matter of beeswax in the study areas is within the acceptable range of national standard.Similar results 0.3335and 0.5491were reportedby Bekele et al.,(2016) and Addisuet al., (2017) respectively. The total volatile matter of the beeswax has no significant variations among study districts (Table 2). However, there is significant variation between samplesources. Accordingly, the beeswax samples collected from 'tej' houses have significantly higher value(0.6265) of total volatile matters than other sources (Table 3).Similarly, higher total volatile matter 0.8077 and 1.5 were obtained from 'tej' houses by Addisu $e t$ al.,(2017) and Yeshitela et al., (2018) respectively.The higher total volatile matter at 'tej' houses might be due to its mishandling andexposures for prolongedsun lights during storages.

\subsection{Acid value, max.}

The acid value in beeswax is determined by measuring the amount of $\mathrm{KOH}$ consumed to neutralize the free acids in 1 gram of wax sample. The acid value $(M e a n+S E)$ of the beeswaxes in the studied area was $22.689 \pm 0.379$,ranging from 18.894 to 26.361 (Table 1). The obtained result shows that it falls within the acceptable national and internationalranges (Table 4).Similar acceptable range of acid values $21.66 \pm 2.26,22.33 \pm 0.39$ and $18.92 \pm 2.7735$ were reported by Nuru (2007b); Bekele et al.,(2016) and Addisuet al.,(2017)respectively. The acid value does not have significant variation based on the source and studied districts, at $\mathrm{p}<0.05$ (Table 1 and 2 ). According to Nuru (2007b), of the total 75 beeswax samples collected from various actors, 8 failed to meet the required standards. 3 of them were from intermediary collector and the remaining 5 were from final processors and exporters.

\subsection{Saponification cloud point, $\mathrm{min},(\mathrm{mg} \mathrm{KOH} / \mathrm{g})$}

The Saponification cloud pointis the amount of Potassium Hydroxide $(\mathrm{KOH})$ required for hydrolyzing $1 \mathrm{~g}$ of sample beeswax. It is one of the simple and preferableparameters used to detect the adulteration of beeswax.However, this method is limited to detect quantities greater than $1 \%$ of higher melting point (i.e. 80$85^{\circ} \mathrm{C}$ ) paraffin waxes and more than $4-5 \%$ of lower melting points $\left(50-55^{\circ} \mathrm{C}\right)$ paraffin(Bonvehi and Bermejo, 2012). The mean Saponification cloud point of the beeswax in the studied areas (Mean+SE) was $94.7540 \pm 0.8617 \mathrm{mg} \mathrm{KOH} /$ granging from 82.1233 to $102.1266 \mathrm{mgKOH} / \mathrm{g}$ (Table 1).Similar acceptable 
results;98.04,91.19 and 93.6were reported byBekeleet al.,(2016), Addisuet al., (2017) and Yeshitelaet al., (2018) respectively.No significant variations were found among studied districts and sources of samples (Table 2 and 3 ).

\subsection{Ester value,(mg KOH/gm)}

Ester value is a measure of Potassium Hydroxide $(\mathrm{KOH})$ required to saponify the ester in $1 \mathrm{~g}$ ofbeeswax sample and it is determined by calculating the difference between Saponification value and acid value.The variation in ester value of beeswax could result from prolonged heat exposures of the beeswax (Nuru, 2007b).

The mean ester value of beeswax samples of the studied areas was72.065 \pm 0.477 , ranging from 67.9702 to 83.233(Table 1).Similar results which are within acceptable ranges (70-79) were reported by Addisu et al.,(2017); Bekeleet al.,(2016) and Nuru (2007b). The mean ester value of the beeswax does not vary significantlyamong studied districts at $\mathrm{p}<0.05$. However, the ester value of beeswax sourced from 'tej' houses has significantly lower values than fresh combs, old combs and processors. The result obtained from current study satisfies both the national and international standards.

\subsection{Ester to acid ratio}

The ester to acid ration is a value obtained when the ester value is divided by its acid value. It indicates whether the wax was stored during longer period or not; as the storage time increased, the ester to acid value will be decreasegradually (Tulloch, 1980). It is not taken as a major quality parameter in Ethiopia and has no acceptable ranges. However, according to Kenyan standards, an acceptable ester to acid ratio should be 3 to 4.3(KBS, 2013). According to the current result, the ester to acid ratio of the studied areas (Mean+SE) isobtained to be 3.201 \pm 0.0625 ranging from 2.493 to 4.405 (Table 1). Equivalent results,3.38 and $3.799 \overline{5}$ was obtained by Bekele ,2016 andAddisuet al, 2017 respectively. The beeswax sampled from 'tej' houses had significantly lower values of ester to acid ratio at $\mathrm{p}<0.05$ than fresh combs, processors and old comb sources. This might be due to prolonged stays of crude beeswax at 'tej' houses with less management. Sometimes some 'tej'housesmay purposively expose it to sunlight to reduce wax moth and small hive beetle attacks. The result shows there is no significant variation of ester to acid values among studieddistricts (Table 2).

\subsection{Fats and fatty acids test}

All sample solutions have passed the test for fats and fatty acids by boiling with $\mathrm{NaOH}$.Sample solutions become clear after acidifying with $4 \mathrm{~N} \mathrm{HCl}($ Table 1$)$.

\subsection{Paraffin and other waxes}

The paraffin and other waxes indicate the contamination or adulteration of natural beeswax with other waxes sources. According to the test result for paraffin and other waxes, all the samples collected in the studied areas have passed the test that the liquid should become cloudy at a temperature lower than $61^{\circ} \mathrm{C}$.
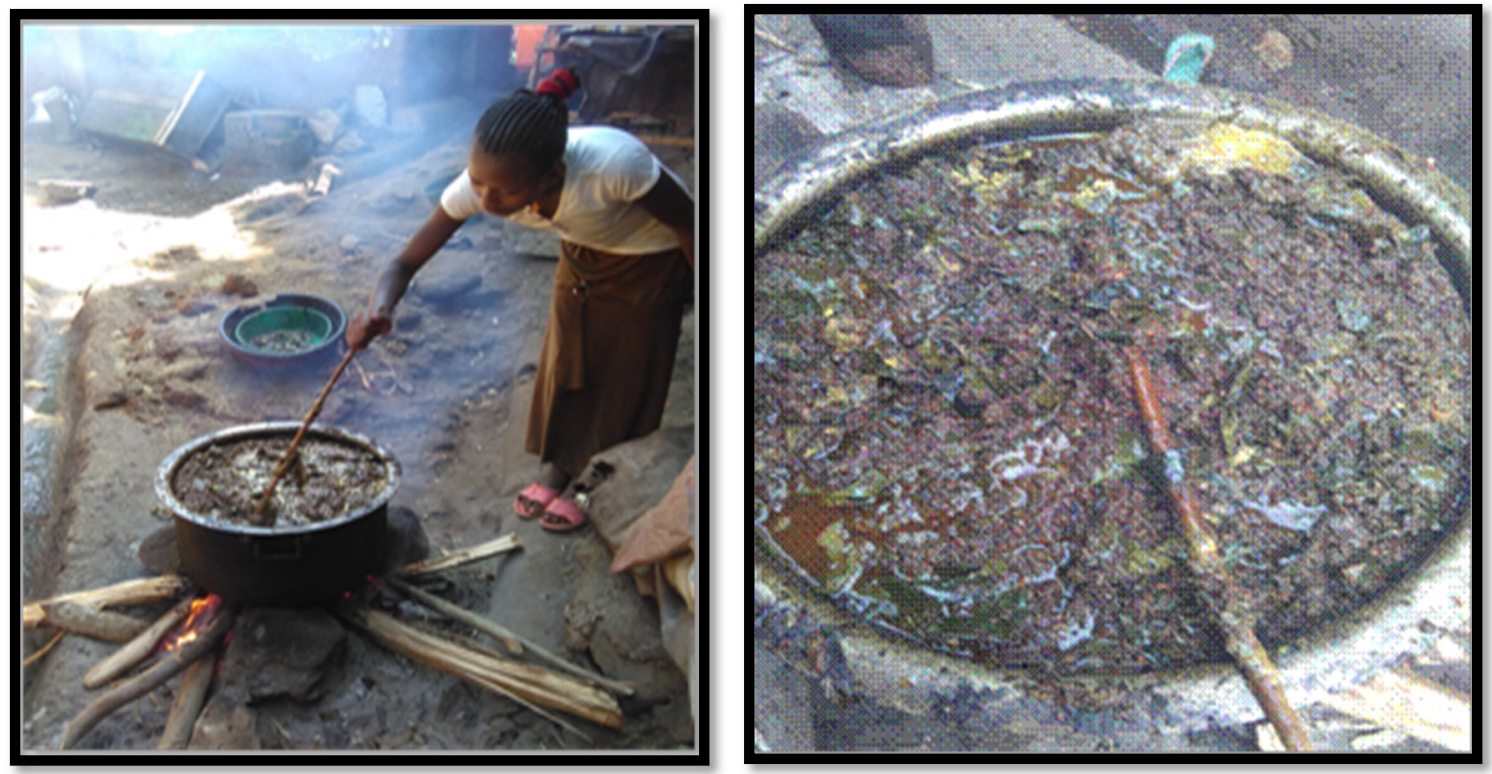

Photo 2: Wax processing at local mead houses (mixed with some 'Rhamnus prinoides' leaves) 
Table1. Physico chemical quality characteristic of beeswax in the study areas Sample $(\mathbf{N}=\mathbf{2 4})$

\begin{tabular}{lll}
\hline parameters & Range & Mean \pm SE \\
\hline Melting point $\left({ }^{\circ} \mathrm{C}\right)$ & $61.00-64.00$ & $62.35 \pm 0.15$ \\
Refractive index & $1.4409-1.4427$ & $1.4416 \pm 0.0001$ \\
Ash content $\%$ by mass) & $0.0115-0.2354$ & $0.0856 \pm 0.0144$ \\
Total volatile matter $(\%$ by mass $)$ & $0.1919-0.8721$ & $0.4156 \pm 0.0385$ \\
Acid value, max & $18.894-26.361$ & $22.689 \pm 0.3793$ \\
Saponification value $\left({ }^{\circ} \mathrm{C}\right)$ & $82.1233-102.1266$ & $94.7540 \pm 0.8617$ \\
Ester value & $67.9702-83.233$ & $72.065 \pm 0.4766$ \\
Ester to Acid ratio & $2.4930-4.405$ & $3.201 \pm 0.0625$ \\
Fats and Fatty acid & - & Passed \\
Paraffin and other waxes & - & Passed \\
\hline
\end{tabular}

$\underline{\mathrm{NB}}-\mathrm{N}=$ is number of samples, $\mathrm{SE}=\mathrm{Standard}$ error of Mean

Table 2. Mean comparison of physicochemical qualities of beeswax by districts

\begin{tabular}{lllll}
\hline \multirow{2}{*}{ Parameters } & \multicolumn{4}{l}{ Districts(Mean+SE) } \\
\cline { 2 - 5 } & Chena $(\mathbf{N}=\mathbf{9})$ & $\mathbf{G i m b o}(\mathbf{N}=\mathbf{8})$ & Gesha $(\mathbf{N}=7)$ & Overall $(\mathbf{N}=\mathbf{2 4})$ \\
\hline Melting point $\left({ }^{\circ} \mathrm{C}\right)$ & $62.17 \pm 0.25$ & $62.63 \pm 0.25$ & $62.29 \pm 0.32$ & $62.35 \pm 0.15^{\mathrm{NS}}$ \\
Refractive index & $1.4416 \pm 0.0002$ & $1.4416 \pm 0.0002$ & $1.4417 \pm 0.0002$ & $1.4416 \pm 0.0001^{\mathrm{NS}}$ \\
Ash content, \% by mass & $0.0809 \pm 0.0245$ & $0.0811 \pm 0.0188$ & $0.0970 \pm 0.0366$ & $0.0856 \pm 0.01448^{\mathrm{NS}}$ \\
Total volatile matter & $0.4151 \pm 0.0619$ & $0.4357 \pm 0.0791$ & $0.4105 \pm 0.0674$ & $0.4207 \pm 0.0385^{\mathrm{NS}}$ \\
Acid value, max & $23.069 \pm 0.533$ & $22.504 \pm 0.7923$ & $22.393 \pm 0.717$ & $22.684 \pm 0.379^{\mathrm{NS}}$ \\
Saponification value $\left({ }^{\circ} \mathrm{C}\right)$ & $95.397 \pm 0.666$ & $93.939 \pm 2.020$ & $94.858 \pm 1.8282$ & $94.754 \pm 0.862^{\mathrm{NS}}$ \\
Ester value & $73.284 \pm 0.612$ & $72.686 \pm 0.963$ & $74.037 \pm 0.971$ & $73.304 \pm 0.477^{\mathrm{NS}}$ \\
Easter to Acid ratio & $3.191 \pm 0.080$ & $3.258 \pm 0.121$ & $3.332 \pm 0.137$ & $3.254 \pm 0.062^{\mathrm{NS}}$ \\
\hline
\end{tabular}

Table 3. Mean comparison of physicochemical properties of beeswax by sources

\begin{tabular}{|c|c|c|c|c|c|}
\hline \multirow[b]{2}{*}{ Parameters } & \multicolumn{5}{|c|}{ Sources (Mean+SE) } \\
\hline & $\begin{array}{l}\text { Freshcombs; } \\
\mathrm{N}=9\end{array}$ & 'Tej'houses; $\mathrm{N}=8$ & $\begin{array}{l}\text { cooperatives; } \\
\mathrm{N}=\mathbf{2}\end{array}$ & Old combs; $N=5$ & Overall \\
\hline Melting point $\left({ }^{\circ} \mathrm{C}\right)$ & $62.33 \pm 0.204$ & $62.38+0.363$ & $62.75 \pm 0.750$ & $62.2 \pm 0.255$ & $62.35 \pm 0.15^{\mathrm{NS}}$ \\
\hline Refractive index & $1.441 \overline{3} \pm 0.0001^{\mathrm{b}}$ & $1.4422 \pm 0.0001^{\mathrm{a}}$ & $1.4413 \pm 0.0002^{b}$ & $1.44 \overline{1} 5 \pm 0.0002^{\mathrm{b}}$ & $1.441 \overline{6}+0.0001$ \\
\hline $\begin{array}{l}\text { Ash content, \% by } \\
\text { mass }\end{array}$ & $0.0224 \pm 0.0022^{\mathrm{b}}$ & $0.1450 \pm 0.0147^{\mathrm{a}}$ & $0.0133 \pm 0.0018^{\mathrm{b}}$ & $0.1334 \pm 0.0333^{\mathrm{ab}}$ & $0.0856 \pm 0.0144$ \\
\hline $\begin{array}{l}\text { Total volatile } \\
\text { matter }\end{array}$ & $0.3334 \pm 0.0244^{\mathrm{b}}$ & $0.6265 \pm 0.0678^{a}$ & $0.3168 \pm 0.0042^{b}$ & $0.2899 \pm 0.0160^{\mathrm{b}}$ & $0.4207 \pm 0.0385$ \\
\hline Acid value, $\max$ & $21.861 \pm 0.579$ & $23.194 \pm 0.7611$ & $21.867 \pm 0.633$ & $23.674 \pm 0.6179$ & $22.684 \pm 0.379^{\mathrm{NS}}$ \\
\hline $\begin{array}{l}\text { Saponification } \\
\text { value }\left({ }^{\circ} \mathrm{C}\right)\end{array}$ & $96.7403 \pm 1.1474$ & $91.3960 \pm 1.6761$ & $95.6710 \pm 1.3278$ & $96.1847 \pm 0.9108$ & $94.7540 \pm 0.8617^{\mathrm{NS}}$ \\
\hline Ester value & $75.324 \pm 0.573^{\mathrm{a}}$ & $70.952 \pm 0.496^{\mathrm{b}}$ & $74.304 \pm 0.195^{\mathrm{ab}}$ & $73.033 \pm 0.478^{\mathrm{ab}}$ & $73.304 \pm 0.477$ \\
\hline $\begin{array}{l}\text { Easter to Acid } \\
\text { ratio }\end{array}$ & $3.463 \pm 0.0879^{\mathrm{a}}$ & $3.082 \pm 0.1026^{\mathrm{b}}$ & $3.401 \pm 0.0895^{\mathrm{ab}}$ & $3.095 \pm 0.0984^{\mathrm{b}}$ & $3.254 \pm 0.0625$ \\
\hline
\end{tabular}

NB: -Letters with different superscripts within a row are significantly difference among sources $(\mathrm{p}<0.05), \mathrm{N}=\mathrm{Number}$ of sample,

$\mathrm{SE}=\mathrm{Standard}$ error of Mean, $\mathrm{NN}=$ Non significant 
Table 4. The mean comparison of wax quality of the study areas with national and international standards

\begin{tabular}{|c|c|c|c|c|c|}
\hline Characteristics/Specification & $\begin{array}{l}\text { Current } \\
\text { result } \\
(\text { Mean } \pm \text { SE })\end{array}$ & $\begin{array}{l}\text { Ethiopian } \\
\text { Standard } \\
(\mathrm{ET} \\
1203 / 2005) \\
*\end{array}$ & $\begin{array}{l}\text { Kenyan } \\
\text { Standard } \\
(\mathrm{CD} \quad / 05- \\
1279: 2013) \\
* *\end{array}$ & $\begin{array}{l}\text { Tanzanian } \\
\text { Standard } \\
\text { (TBS/ } \\
\text { AFDC } \\
17 / 4049) \\
* * *\end{array}$ & $\begin{array}{l}\text { European } \\
\text { Pharmacopeias } \\
\text { (ET 1203/2005) } \\
*\end{array}$ \\
\hline Melting point $\left({ }^{\circ} \mathrm{C}\right)$ & 623 & $61-66$ & $62-65$ & $62-65$ & $61-65$ \\
\hline Refractive index, at $75^{\circ} \mathrm{C}$ & $1.4416 \pm 0.0001$ & $\begin{array}{l}1.4400- \\
1.4450\end{array}$ & $\begin{array}{l}1.4398 \\
1.4455\end{array}$ & $\begin{array}{l}1.4398 \\
1.4455\end{array}$ & $1.440-1.4450$ \\
\hline Ash, $\%$ by mass, max. & $0.0808 \pm 0.0144$ & 0.20 & 0.6 & 0.6 & - \\
\hline Total volatile matter, max & $0.4207 \pm 0.0385$ & 0.75 & - & 1 & - \\
\hline Acid value, max & $22.684+0.379$ & $17-24$ & $17-24$ & $17-24$ & $18-23$ \\
\hline Saponification value, $\min$. & $94.7540 \pm 0.8616$ & $85-105$ & - & $87-104$ & $87-104$ \\
\hline Ester value & $73.304+0.477$ & $70-80$ & $70-79$ & $70-79$ & $70-80$ \\
\hline Ester to Acid ratio & $3.254+0.0625$ & - & $3.0-4.3$ & - & - \\
\hline Fats and Fatty acids & Passed & $\begin{array}{l}\text { To pass } \\
\text { test }\end{array}$ & To pass test & To pass test & - \\
\hline Paraffin and other waxes & Passed & $\begin{array}{l}\text { To pass } \\
\text { test }\end{array}$ & To pass test & To pass test & Absent \\
\hline
\end{tabular}

Notice: $\mathrm{N}=$ Number of sample, $\mathrm{SE}=\mathrm{Standard}$ error of Mean, -= not available; Source: * (QSAE, 2005), ** (KBS, 2013), *** (TBS, 2010)

\section{CONCLUSION AND RECOMMENDATIONS}

In the study areas,local retailers, whole sellers, 'tej' houses, local collectors, cooperatives and private companiesare identified as the major honey and beeswaxmarket chain actors. However, 'tej 'houses and cooperatives are identified to be the major actors taking part in processing and marketing of beeswax.In spite of its less production, the ways of managing beeswax in general and 'tej' houses in particular is very poor which is prone for contaminations and some intentionally added preservatives basically ' $\mathrm{NaCl}$ ' which is used for preserving the beeswax from waxmoth attacks might have also its own impacts resulting for some deviations in some parameters of waxes from local mead houses.According to the laboratory results, all the beeswax samples in the area taken from different sources(from 'tej' houses, honey combs, old combs and cooperatives) are found within the acceptable range of both national and international standards in all parameters which indicates the beeswax product in the studied areas ismostly natural.

Based on the present study findings, the following points can be forwarded and recommended:

- Awareness creation and follow-ups on appropriate management aspects of beeswax products should be given forbeeswax producers andmarket actors in general and 'tej' house owners in particular.

- The inclusion rates of preservatives $(\mathrm{NaCl})$ and other adulterants especially at local mead houses need further investigation, and their effectson the quality of beeswax require follow up studies.

- Moreover, local quality assurance entities for beeswax should be established for regular quality monitoring.

\section{REFERENCES}

Addisu, B., Desalegn, B., Asaminew, T. and Zeleke, M. (2017). Physico chemical properties of Ethiopian Beeswax, the case of South Wollo zone, Amhara Region. International Journal of Agricultural Science Food Technology, 3(3): pp61-66. http://doi.org/10. 17352/2455-815X.000024

Bekele,T., Dessalegne, B. and Mitiku, E. (2016). Analysis of Physico-Chemical Properties of Beeswax Produced in Bale Natural Forest, South-Eastern Ethiopia. European Journal of Biophysics, 4(5): pp42-46

Bogdanov, S. (2004b). Quality and standards of pollen and beeswax. Apiacta 38(2004) pp 334-341.

Bogdanov, S. (2009). Beeswax: Production, Properties, Composition and Control. In The Beeswax Book (pp. 117).

Bogdanov, S. (2016a). Beeswax: Production, Properties Composition and Control. In The Beeswax Book.

Bogdanov, S.(2004a). Beeswax: quality issues today. Bee World, 85(4), 46-50. Retrieved from: www.ibra.org.uk Bogdanov, S.(2016b)..Bees wax: history, uses and trade. Bee Product Science. Chapter.2. (www.bee-hexagon net) Bradbear, N. (2009). NON-WOOD FOREST PRODUCTS: Bees and their role in forest livelihoods. A guide to the services provided by bees and the sustainable harvesting, processing and marketing of their products. Rome, 
Italy.

Brian, T.M. (2015). The Contribution of Apiculture towards Rural Income in Honde Valley Zimbabwe; Presented at the National Capacity Building Strategy for Sustainable Development and Poverty Alleviation Conference (NCBSSDPA 2015), May 26-28, 2015, American University in the Emirates, Dubai.

Brown, R. (2010). Beekeeping: a seasonal guide: London, UK: BT Batsford Ltd.

EPOPA (2006). Export Opportunities for African Organic Honey and Beeswax: A Survey of the Markets in Germany, the United Kingdom, and the Netherlands., (January). Retrieved from: http://www.grolink.se/epopa/Publications/Market-studies/EPOPA_marketsurveyhoney-Jan06-web.pdf

Gemechis, L.(2014). Beeswax Production and Marketing in Ethiopia: Challenges in Value Chain. Agriculture, Forestry and Fisheries, 3(6): pp447-451.

Hilmi, M., Bradbear, N. and Mijia, D.(2011). The feasibility of the ivelihood of beekeeping. Beekeeping and sustainable livelihoods. FAO Diversification Booklet-1. $2^{\text {nd }}$ ed.

Nuru, A.(2007b). Physical and Chemical Properties of Ethiopian Beeswax and Detection of Adulteration. Ethiopian Journal of Animal Production (EJAP), 7(1), 39-48.

Tulloch, A. P. (1980). Beeswax - composition and analysis. Bee World, 61:pp 47-62.

Yeshitela, E., Demelash, Z., Hana, T., Tigist, L., Tekeba, E. and Taye,N.(2018). Determination of the proportion of pure beeswax recovered from crude beeswax resources at local honey wine making houses in Ethiopia. Journal of Nutritional, Health and Food Engineering; vol.8(3). 